\title{
Financial Inclusion and Its Impact on Inclusive Growth: The Macro-Economic Perspective in Sri Lanka
}

\author{
Kumari, D.A.T. \\ Department of Banking and Finance, Wayamba University of Sri Lanka, Kuliyapitiya \\ *Corresponding Author: \\ Email:datkumari@gmail.com,datkumari@myb.ac.lk.
}

\begin{abstract}
The term "Financial Inclusion" means the transfer of formal financial services at a reasonable cost to the vast sections of underprivileged and low-income group of the country. Financial inclusion and inclusive growth are the two sides of the same coin. Both are interrelated and interdependent. For growth to be inclusive, all people should access and use the formal financial services. In Sri Lanka, it is apparent that the inclusive growth is hampered by financial exclusion. Mostly, banking and other financial services are not distributed adequately, especially in rural areas of the country. Therefore, there is a large part of the rural population that involve in high risky informal financial transactions thereby involving with the informal financial sector. The present study attempt to examine the contribution of financial inclusion to enhance the inclusive growth of the country. This study concerned economic growth, poverty, equality and employment as main dimensions of the inclusive growth. As per the nature of the study, secondary data were collected from literature and other accepted reports. The research employed a regression model using E-views to analyse time series data from the period of 1985 to 2019 . According to the findings of the research, results revealed that there is a significant positive impact made by the financial inclusion on the inclusive growth of the country. Further, the results explained economic growth as the most significant determinant and employment as the least significant determinant which is influenced by the financial inclusion in the Sri Lankan context.
\end{abstract}

KEYWORDS: Economic growth, Financial inclusion, Inclusive growth

\section{Introduction}

In simply, financial inclusion is the access and usage of a financial intermediation process. Financial intermediation is the process of channelling funds from those who wish to lend or invest to those who wish to borrow or require investment funds (Goacher, 1999). On the other hand, Goacher (1999) points out that financial intermediation performs the essential economic function of channelling funds from households, firms and the government that have saved surplus funds by spending less than their income to those that have a shortage of funds because they wish to spend more than their income. Financial intermediaries are financial institutions through which savers can indirectly provide funds to borrowers (Aduda and Kalunda, 2012). So the term intermediation reflects the role of these institutions which stand between savers and borrowers.

(C) Department of Agribusiness Management 
Throughout the process, financial intermediaries are facilitating financial inclusion among the financial system (Akudugu, 2013).

When examining the significances of financial inclusion, at early stages of the world economies mainly focused on economic growth (Schumpeter, 1911; Hicks, 1969). In the inclusive financial system, it is easier for individuals to access financial services, and this improves the daily transactions of individuals and finally improves the country's economic growth. Therefore, the relationship between financial market development and economic development has always been an important topic in economics. According to Park et al., (2015), the role of financial intermediation on economic growth and development is not well understood and is still widely debated among economists (Park et al., 2015). For instance, the direction of causality is not clear: Does development lead to financial development or is it the case that financial development leads to economic growth? It is likely that the causality runs both ways and separating these effects is not an insignificant task. Early works by Schumpeter (1911) and Hicks (1969) found that financial development causes economic growth. However, Robinson (1952) and Levine (1997) argue that economic growth promotes financial development. According to the studies of Robinson (1952) and Levine (1997), economic growth creates demand and the automatic response of the financial system to this demand causes development of the financial system (Park et al., 2015). An inclusive financial system promotes effective allocation of productive resources, and a more efficient use of resources will likely reduce the cost of capital (Levine, 1997). If the inclusive financial system comes at a relatively high cost, the system can reduce the inefficiencies in credit markets from its informal credit sectors (Agarwal, 2010). Thus, it is possible that countries can enhance efficiency and welfare using an all-inclusive financial system by providing ways for secure and safe saving practices and by promoting efficient financial services.

Even though the countries are able to achieve high economic growth, poverty and income inequality remain a major challenge in the world today, despite the rapid financial and economic expansion seen in the past decade, which has lifted millions out of poverty. Therefore, world economists as well as policy makers are much more concerned about inclusive growth rather than economic growth. Hence the trend has now shifted from financial inclusion through the debate on economic growth to financial inclusion through the debate on inclusive growth (Bill and Melinda, 2015; Park et al., 2015). For this reason, the majority of countries set their economic policies to promote financial inclusion as a determinant of inclusive growth.

As a result, recent policy makers suggested that the economic policies have to focus on financial inclusion as a crucial factor for inclusive growth. A good example is, the World Bank's declared objective of achieving universal financial access by 2020 . Not only that, as Park et al. pointed out in 2015, "present economics scenario also changed from economic growth to inclusive growth1" (Park et al., 2015). Further, inclusive growth is one of the ADB's strategic pillars.

\footnotetext{
1 The World Bank: defines inclusive growth by its pace and pattern - growth that is sufficient to lift large numbers out of poverty and growth that includes the largest part of the country's labour force in the economy.
}

(C) Department of Agribusiness Management 
Strategy 2020 identifies inclusive growth as one of the ADB's three strategic pillars, along with environmental sustainability and regional integration (Klasen, 2010).

As a result of high degree of financial inclusion some countries achieved a high economic growth. And also it implied that these countries already gained high inclusive growth as shown in table 1.

Table 1: Financial Inclusion and Inclusive Growth

Financial Inclusion

\begin{tabular}{|c|c|c|c|c|c|c|}
\hline $\begin{array}{c}\text { In } \\
\text { Year } \\
2018\end{array}$ & $\begin{array}{c}\text { Economic } \\
\text { Growth } \\
\text { (GDP } \\
\text { growth) }\end{array}$ & OR & $\begin{array}{c}\text { GDP } \\
\text { per } \\
\text { capita } \\
\text { Income } \\
(\$)\end{array}$ & $\begin{array}{c}\text { Poverty } \\
\text { (Poverty } \\
\text { Headcount } \\
\text { Ratio) }\end{array}$ & $\begin{array}{l}\text { Equality } \\
\text { (Gini } \\
\text { Index })^{*}\end{array}$ & $\begin{array}{c}\text { Employment } \\
\text { (Unemployment } \\
\text { Rate) }\end{array}$ \\
\hline
\end{tabular}

\begin{tabular}{|c|c|c|c|c|c|c|}
\hline Sri Lanka & $73.6 \%$ & $3.3 \%$ & 4081 & $4.1 \%$ & 51.4 & $4.12 \%$ \\
\hline Indonesia & $48.9 \%$ & $5.2 \%$ & 3894 & $9.8 \%$ & 37.8 & $4.51 \%$ \\
\hline India & $79.9 \%$ & $6.1 \%$ & 3970 & $6.7 \%$ & 47.9 & $5.8 \%$ \\
\hline Pakistan & $21.3 \%$ & $5.8 \%$ & 1482 & $24.3 \%$ & 36.2 & $4.08 \%$ \\
\hline Malaysia & $85.3 \%$ & $4.8 \%$ & 11377 & $5.6 \%$ & 42.8 & $3.35 \%$ \\
\hline Sour & \multicolumn{6}{|c|}{$\begin{array}{l}\text { World Bank Indicator - Data Bank. 2018, The little Data Book on Financial Inclusion 2018, International } \\
\text { Monetary Fund } 2018\end{array}$} \\
\hline $\begin{array}{l}{ }^{*} \text { Gini- } \\
\text { Index: }\end{array}$ & \multicolumn{6}{|c|}{$\begin{array}{l}\text { This index measures the degree of inequality in the distribution of family income in a country. If income were } \\
\text { distributed with perfect equality, the Lorenz curve would coincide with the } 45 \text { degree line and the index would } \\
\text { be zero; if income were distributed with perfect inequality, the Lorenz curve would coincide with the horizontal } \\
\text { axis and the right vertical axis and the index would be } 100\end{array}$} \\
\hline
\end{tabular}

Accordingly, previous researchers (for examples: Magap et al., 2015; Bill and Melinda, 2015; Park et al., 2015; Dixit and Ghosh, 2013) in economics, explained that the economic policy targets should be cantered to achieve inclusive growth for any country. As pointed out by Chakrabarty and Chaudhuri (2001), "If we are talking of financial stability, economic stability and inclusive growth with stability, it is not possible without achieving financial inclusion. Thus financial inclusion is no longer a policy choice but is a policy compulsion today. And banking is a key driver for inclusive growth" (Chakrabarty and Chaudhuri (2001). According to Rauniyar and Kanbur in 2010, explained inclusive growth as: "Growth that is accompanied by declining income inequality" (Rauniyar and Kanbur, 2010). Roy (2012), pointed out that, "Access to finance, especially by the poor and vulnerable groups, is an essential requisite for employment, economic growth, poverty alleviation and social up liftmen for achieving inclusive growth" (Roy, 2012). Therefore, it is evident that, financial inclusion facilitates greater participation by different segments of the population in the formal financial system.

(C) Department of Agribusiness Management 
Hence, understanding the relationship between financial inclusion, poverty, unemployment and income inequality at the country level will help policymakers to design and implement programs that will broaden access to financial services, leading to a reduction of poverty incidence to employment, to income equality and finally to inclusive growth. Therefore, investigating whether financial inclusion has influenced on inclusive growth in the Sri Lankan context is a pertinent research problem.

Therefore, in this study, researcher is planning to examine the financial inclusion and its impact on inclusive growth. Accordingly, the current study attempts to examine to what extent financial inclusion impacts on inclusive growth in Sri Lanka in the macro perspective. For that purpose, the study plans to use regression models to identify the significance influence of financial inclusion on inclusive growth in Sri Lanka.

\section{Research Objectives}

Based on the research problems addressed there are a few research objectives identified in the study. The key objective of the study is to examine the influenced made by financial inclusion on inclusive growth in Sri Lanka. In addition to the key objective, researcher needed to test the influenced made by the financial inclusion on dimensions of an inclusive growth separately. Therefore, researcher formulated four specific objectives as follows targeting on every dimension; (1) to investigate the influence made by the financial inclusion on economic growth of the country, (2) to examine the influence made by the financial inclusion on employment level of the country, (3) to examine the influence made by the financial inclusion on poverty reduction of the country, (4) to evaluate the influence made by the financial inclusion on income equality of the country.

\section{Literature Review}

"Inclusive growth could be defined as mainly benefiting groups that are otherwise disadvantaged; such growth is more appropriately defined as disadvantage-reducing growth. In this regard, one could think particularly about growth that reduces regional, ethnic, or gender disadvantages, and this might be one useful way to differentiate an outcome-focus of inclusive growth from pro-poor growth" (Klasen, 2010).

Ramos et al., (2013) follow the concept of benefit sharing and participation to measure inclusiveness. Inclusiveness of growth is the growth elasticity of poverty in the sense that poverty reduction has been the overall objective of any policy debate over a period of time (Thorat, 2006). Inclusive growth depends upon two factors (a) income growth and (b) income distribution (Anand et al., 2013). Financial inclusion facilitates greater participation by different segments of the population in the formal financial system. Finance is vital for inclusive growth, because the financial market is the mother of all markets. Hence financial inclusion is critical to achieving inclusive growth in the economy (Magap et al., 2015).

Inclusive growth involves both poverty and inequality reduction. Agarwal (2010) define inclusive growth as the growth process that increases the social opportunity function which depends upon the average opportunities available to the population and how these opportunities are shared among the population. 
According to Agarwal (2010) the key elements in inclusive growth are employment and productivity, development in human capabilities and social safety nets and the targeted intervention. Providing access to financial services has significant potential to help lift the poor out of their cycle of poverty.

According to Dixit and Ghosh in 2013, financial inclusion promotes thrift and develops a culture of saving and also enables efficient payment mechanisms thereby strengthening the resource base of the financial institution which benefits the economy as resources become available for an efficient payment mechanism and allocation (Dixit and Ghosh, 2013). Further, Dixit and Ghosh (2013) explained that, the poor are typically more vulnerable to financial exclusion. This is simply because their major problems arise from the need for finances. The formal banking services, by exploiting economies of scale and making judicious use of targeted subsidies may reduce or remove market imperfections and facilitate financial inclusion of the poor, ultimately leading to higher incomes (Dixit and Ghosh, 2013). The access to financial services by the poor would lead to their consumption smoothing and investments in health, education and income generating activities, thus expanding growth opportunities for them (Kumar, 2013).

This definition of inclusive growth reveals a direct link between the micro and macro determinants of growth (Klasen, 2010). In reviewing the ADB literature, Rauniyar and Kanbur (2010) point out that while there is no agreed and common definition of inclusive growth or inclusive development, the term is understood to refer to "growth coupled with equal opportunities and consisting of economic, social and institutional dimensions. They further point out that inclusive growth is accompanied by lower income inequality so that the increment of income accrues disproportionately to those with lower incomes (Rauniyar and Kanbur, 2010).

\section{Methodology}

According to the research problem and objectives, the study should examine the financial inclusion and its impact on inclusive growth. Further, the relationship between financial inclusion and inclusive growth dimensions can be estimated in the macro perspective. Keeping these arguments in mind, the researcher developed the conceptual model for the study (Figure 1).

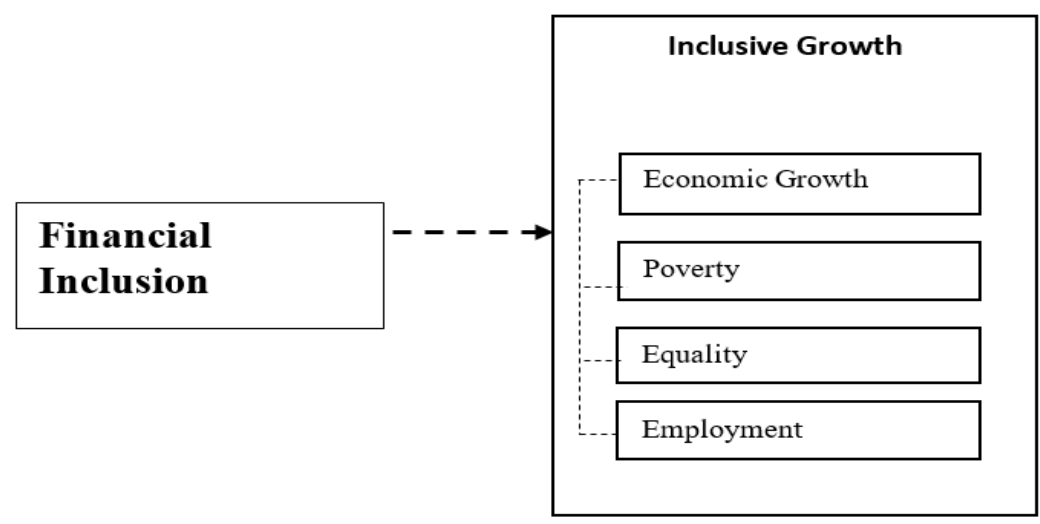

Figure 1: Conceptual Framework 


\section{Formulating the Hypotheses}

The present study is cantered on evaluating key consequences of financial inclusion. Further, financial inclusion and its impact on the dimensions of inclusive growth tested on macroeconomic perspective. Therefore, study attempt to evaluate the relationship between inclusive growths as a main consequence of financial inclusion in the macro perspective. To this end, the author developed a few hypotheses based on the relationship among variables demonstrated in the conceptual framework. According to the details given in the above sections, influenced of financial inclusion investigated based on quantitative data. Therefore, hypotheses were tested to demonstrate the relationship between financial inclusion and inclusive growth. According to the previous literature, the majority of research has tested the consequences of financial inclusion and their influence on the degree of financial inclusion (Shankar, 2011; Perera, 2015; Heenkenda, 2014). Study have also tested inclusive growth as a major consequence of financial inclusion (Magap et al., 2015; Bill and Melinda, 2015; Park et al., 2015; Dixit and Ghosh, 2013). In this situation researchers have formulated models and they have built relevant hypotheses for analysis. While taking into account those hypotheses the present researcher also formulated a few hypotheses and was planned to test them. Therefore, the researcher has developed a few hypotheses for the macro perspective of the study as given below.

As per the literature, most researchers attempted to find the impact of financial inclusion on inclusive growth (Vellala et al., 2014; Serrao et al., 2013; Magap et al., 2015; Bill and Melinda, 2015). They pointed out financial inclusion as a tool for achieving inclusive growth. Generally, financial inclusion always achieves the same results which are considered basic determinants of inclusive growth (Anand et al., 2013; Islam, 2014). For instance, financial inclusion works towards creating employment, reducing poverty and supporting high earning while mitigating risk and finally it will result in the reduction of inequality. Taking into consideration these conceptual relationships, the researcher formulated some hypotheses to test the consequences of financial inclusion. Thus, the author developed H1; as a main hypothesis to determine the influence of financial inclusion on inclusive growth:

\section{H1: Financial inclusion is positively influenced on an inclusive growth in Sri Lanka}

Financial inclusion facilitates greater participation by different segments of the population in the formal financial system. Finance is vital for inclusive growth because the financial market facilitates all financial transactions of all kinds of markets; hence financial inclusion is critical to achieving inclusive growth in the economy (Kumar and Mohanty, 2011); Magap et al., 2015; Bill and Melinda, 2015; Park et al., 2015).

The main instrument for sustainable and inclusive growth is assumed to be productive economic growth (Dixit and Ghosh, 2013). Therefore, a compulsory first step for inclusive growth is achieving high economic growth for the economy. Financial inclusion is a significant variable which helps people to achieve individual income and ultimately gain economic growth.

(C) Department of Agribusiness Management 
Inclusive growth is about raising the pace of growth and enlarging the size of the economy, while leveling the playing field for investment and increasing productive employment opportunities (Ellis, 2007; Chakrabarty, 2010). Further, the concept of productive employment as a fundamental element of inclusive growth was stressed by Bhanot et al. (2012).

An inclusive growth strategy encompasses the key elements of an effective poverty reduction strategy and, more importantly, expands the development agenda. Developing inclusive financial systems which are financially and socially sustainable, as a poverty reduction strategy, should be given priority (Anna et al., 2010). Levine, (1997), and Beck et al., (2007) have noticed a positive effect of finance on poverty reduction. Economies with higher levels of financial development experience faster reduction of poverty. This has been explained by an extensive body of literature including Devlin, (2009), Verma, and Aggarwal, (2014). In an often cited cross-country study, Zuleika (2010) proves that growth in average incomes explains 70 percent of the variation in poverty reduction (as measured by the headcount ratio) in the short run, and as much as 97 percent in the long run. Yunus (2011), suggest that for a given inequality intensity, the poorer the country is, the more vital is the growth component in explaining poverty reduction. Thus, equitable growth is indeed an imperative for inclusive growth.

"Inequality matters for growth and other macroeconomic outcomes, in all corners of the globe" (Berger and Udell, 2002). Inequality was found to matter particularly for the long-term sustainability of growth (Arora, 2010); Rauniyar and Kanbur (2010) pointed out that inclusiveness - that is, income inequality reduction, according to their view - can be more or less pro-poor depending on which income levels are more positively affected, and accordingly argue that the focus of policy for poverty reduction must be growth that increases the lowest incomes.

Financial inclusion implies a direct link to creating new jobs opportunities through capital accumulation and investments. Inclusive growth refers both to the pace and pattern of growth, which are considered interlinked, and therefore in need to be addressed together. The idea that both the pace and pattern of growth are critical for achieving a high, sustainable growth record, as well as poverty reduction, is consistent with the findings in the previous literature. For instance: Ramos et al., Dixit and Ghosh, 2013; Ramos et al., 2013; Kumar, 2013; Kumari, 2012; Kumari , 2016a; 2016b. These researchers noted that inclusiveness, a concept that encompasses equity, equality of opportunity, and protection in market and employment transitions is an essential ingredient of any successful growth strategy. Here the present study emphasizes the following hypotheses as sub hypotheses of $H 1$ as afore mentioned. Specifically,

H1a: Financial inclusion is significantly influenced to economic growth in Sri Lanka
H1b: $\quad$ Financial inclusion is significantly influenced to employment in Sri Lanka
H1c: $\quad$ Financial inclusion is significantly influenced to poverty level in Sri Lanka
H1d: $\quad$ Financial inclusion is significantly influenced to income equality in Sri Lanka

(C) Department of Agribusiness Management 


\section{Results and Discussion}

As secondary data gathered from publications, the researcher employed regression model using E-views as a facilitating software for data analysis of time series data. In the macro aspect, researcher attempted to test the impact of financial inclusion on inclusive growth. Finally, the researcher investigated the impact of financial inclusion on determinants of inclusive growth separately. Accordingly, the impact of financial inclusion was tested with respect to the economic growth, employment, inequality and poverty, and those were tested by using simple regression models.

\section{Hypotheses Testing}

\section{Financial Inclusion and Inclusive Growth}

Main hypothesis was formulated to examine the impact made by the financial inclusion on an inclusive growth and tested.

\section{H1: Financial Inclusion is Positively Influenced on Inclusive Growth in Sri Lanka}

Following table 2 shows the simple regression analysis result between financial inclusion and inclusive growth

\section{Table 2: Regression Results of Financial Inclusion on Inclusive Growth}

\begin{tabular}{lcccc}
\hline Variable & Coefficient & Std. Error & t-Statistic & Prob. \\
\hline C & 3.74 & 0.151 & 25.18 & 0.00 \\
FININ & 0.23 & 0.04 & 6.32 & 0.00 \\
\hline R-squared & 0.55 & Mean dependent var & 4.67 \\
Adjusted R-squared & 0.54 & S.D. dependent var & 0.10 \\
S.E. of regression & 0.06 & Akaike info criterion & -2.57 \\
Sum squared resid & 0.14 & Schwarz criterion & -2.49 \\
Log likelihood & 47.06 & Hannan-Quinn criter. & -2.54 \\
F-statistic & 39.89 & Durbin-Watson stat & 0.62 \\
Prob (F-statistic) & 0.00 & & \\
\hline
\end{tabular}

According to the regression result, $\mathrm{R}$-squared value $\left(\mathrm{R}^{2}=55 \%\right)$ of the model is in moderate level and the probability level (F-statistic 0.00) of the model is significant. Since the overall influence of financial inclusion is $54.7 \%$ on inclusive growth including economic growth, productive employment, poverty reduction and income equality while balance of $45.3 \%$ is influenced by other variables which exist outside from the study area. The result of this model shows that financial inclusion (P-value 0.00) is significant at the $5 \%$ significant level. Constant value of the model is 3.74 . 
If there is no financial inclusion or zero financial inclusion, inclusive growth of the country would be 3.74. Further coefficient for the financial inclusion is 0.23 . If financial inclusion increases by 1 unit, it leads to 0.23 increases in inclusive growth. DurbinWatson stat (0.62) of the model is near to 0 , since it implies the positive autocorrelation of the model. Accordingly, the hypothesis of $\mathrm{H} 1$ can be accepted as per the statistical result of the model. Therefore, the empirical evidences supported to prove the theoretical causal relationship between financial inclusion and inclusive growth. In addition to that, to identify the mostly affected determinants of the inclusive growth, there are four sub hypotheses were formulated and four simple regressions were tested respectively.

\section{Financial Inclusion and Economic Growth}

To value the inclusive growth of the country, economic growth is the sub variable which is using per capita income as the measure of it. Subsequently, per capita income is the measurement indicator of the economic growth.

Hypothesis testing was conducted to analyse the relationship between financial inclusion and economic growth base on the following hypothesis.

\section{H1a: Financial Inclusion is Significantly Influenced on Economic Growth in Sri Lanka}

By referring received data from past 35 years the statistical analysis between financial inclusion and the (per capita income) economic growth can be shown through the following table 3 .

Table 3: Regression Results on Financial Inclusion and Economic Growth

\begin{tabular}{lcccc} 
Variable & Coefficient & Std. Error & t-Statistic & Prob. \\
\hline C & -4.03 & 1.65 & -2.45 & 0.02 \\
FININ & 3.74 & 0.40 & 9.40 & 0.00 \\
\hline R-squared & 0.73 & Mean dependent var & 11.42 \\
Adjusted R-squared & 0.72 & S.D. dependent var & 1.36 \\
S.E. of regression & 0.72 & Akaike info criterion & 2.24 \\
Sum squared resid & 17.15 & Schwarz criterion & 2.33 \\
Log likelihood & -37.18 & Hannan-Quinn criter. & 2.27 \\
F-statistic & 88.45 & Durbin-Watson stat & 0.08 \\
Prob (F-statistic) & 0.00 & & \\
\hline
\end{tabular}

According to the regression result, $\mathrm{R}$-squared value $\left(\mathrm{R}^{2}=73 \%\right)$ of the model is good and the probability level (F-statistic 0.00 ) of the model is significant. Hence the overall influence of financial inclusion is $72.8 \%$ on economic growth while balance of $27.2 \%$ is influenced by other variables which exist outside from the study area. 
The result of this model shows that financial inclusion (P-value 0.00) is significant at the $5 \%$ significant level. Constant value of the model is -4.03 . If there is no financial inclusion or zero financial inclusion, economic growth of the country would be -4.03 . Further coefficient for the financial inclusion is 3.74. If financial inclusion increases by 1 unit, it leads to 3.74 increases in economic growth of the country. Durbin-Watson stat $(0.08)$ of the model is near to 0 , since it implies the positive autocorrelation of the model. The hypothesis of H1a can be accepted as per the statistical result of the model. It further, confirmed that the theoretical and empirical evidences were also supported in the present research context.

\section{Financial Inclusion and Productive Employment (Employment)}

Productive Employment is one of the sub variables that measure the inclusive growth. The unemployment ratio is the measurement indicator of the productive employment.

Subsequently, the following hypothesis testing was conducted to analyse the relationship between financial inclusion and productive employment.

\section{H1b: Financial Inclusion is Significantly Influenced on Employment in Sri Lanka}

Below table shows the simple regression result between financial inclusion and productive employment of the model.

Table 4: Regression Results on Financial Inclusion and Unemployment

\begin{tabular}{lcccc}
\hline Variable & Coefficient & Std. Error & t-Statistic & Prob. \\
\hline C & 7.57 & 0.68 & 11.18 & 0.00 \\
FININ & -1.33 & 0.16 & -8.11 & 0.00 \\
\hline R-squared & 0.67 & Mean dependent var & 2.09 \\
Adjusted R-squared & 0.66 & S.D. dependent var & 0.51 \\
S.E. of regression & 0.30 & Akaike info criterion & 0.46 \\
Sum squared resid & 2.90 & Schwarz criterion & 0.55 \\
Log likelihood & -6.05 & Hannan-Quinn criter. & 0.49 \\
F-statistic & 65.84 & Durbin-Watson stat & & 0.22 \\
Prob (F-statistic) & 0.00 & & \\
\hline
\end{tabular}

According to the regression result, $\mathrm{R}$-squared value $\left(\mathrm{R}^{2}=66 \%\right)$ of the model is good and the probability level (F-statistic 0.00 ) of the model is significant. Hence the overall influence of financial inclusion is $66.6 \%$ on productive employment while balance of $33.4 \%$ is influenced by other variables which exist outside from the study area. The result of this model shows that financial inclusion (P-value 0.00 ) is significant at the $5 \%$ significant level. Constant value of the model is 7.57. 
If there is no financial inclusion or zero financial inclusion, unemployment of the country would be 7.57. Further coefficient for the financial inclusion is -1.33 . If financial inclusion increases by 1 unit, the unemployment decreases by 1.33 units. Durbin-Watson stat $(0.22)$ of the model is near to 0 , since it implies the positive autocorrelation of the model. The hypothesis of $\mathrm{H} 1 \mathrm{~b}$ has been accepted as per the statistical result of the model. It further evidence for the theoretical relation as well which shows that there is a negative relationship between these two variables in practice.

\section{Financial Inclusion and Poverty}

Poverty is a sub variable that measures the inclusive growth. The head count ratio is the measurement indicator of the poverty.

Subsequently, the following hypothesis testing was conducted to analyse the relationship between financial inclusion and poverty.

\section{H1c: Financial Inclusion is Significantly Influenced on Poverty Level in Sri Lanka}

Following table shows the simple regression analysis result between financial inclusion and poverty level of the model.

Table 5: Regression Results of Financial Inclusion and Poverty

\begin{tabular}{lcccc}
\hline Variable & Coefficient & Std. Error & t-Statistic & Prob. \\
\hline C & 8.76 & 1.55 & 5.65 & 0.00 \\
FININ & -1.74 & 0.37 & -4.65 & 0.00 \\
\hline R-squared & 0.40 & Mean dependent var & 1.57 \\
Adjusted R-squared & 0.38 & S.D. dependent var & 0.86 \\
S.E. of regression & 0.68 & Akaike info criterion & 2.12 \\
Sum squared resid & 15.19 & Schwarz criterion & 2.21 \\
Log likelihood & -35.06 & Hannan-Quinn criter. & 2.15 \\
F-statistic & 21.65 & Durbin-Watson stat & & 0.13 \\
Prob (F-statistic) & 0.00 & & \\
\hline
\end{tabular}

According to the regression result, $\mathrm{R}$-squared value $\left(\mathrm{R}^{2}=39 \%\right)$ of the model is indicated at moderate level and the probability level (F-statistic 0.00 ) of the model is significant. Hence the overall influence of financial inclusion is $39.6 \%$ on poverty, while balance of $60.4 \%$ is influenced by other variables which exist outside from the study area. The result of this model shows that financial inclusion (P-value 0.00 ) is significant at the $5 \%$ significant level. Constant value of the model is 8.76 . If there is no financial inclusion or zero financial inclusion, poverty level of the country would be 8.76 . Further coefficient for the financial inclusion is -1.74 . If financial inclusion increases by 1 unit, the head count ratio decreases by 1.74 units. 
Durbin-Watson stat (0.13) of the model is near to 0 , since it implies the positive autocorrelation of the model. The hypothesis of $\mathrm{H} 1 \mathrm{c}$ has been accepted as per the statistical result of the model. According to the theoretical background, it explained that there is a negative relationship between financial inclusion and poverty level. On the other way round, it is said that, if the country is having more financially included people, then the country would abled to reduce the poverty level.

\section{Financial Inclusion and Income Equality}

Income Equality is the last sub variable of the inclusive growth. It uses Gini coefficient to measure the income equality.

The hypothesis that mentioned below was used to analyse the relationship between financial inclusion and income equality.

\section{H1d: Financial Inclusion is Significantly Influenced on an Income Equality in Sri Lanka}

The regression result of the model shows by the following table.

Table 6: Regression Results on Financial Inclusion and Income Equality

\begin{tabular}{lcccc} 
Variable & Coefficient & Std. Error & t-Statistic & Prob. \\
\hline C & 2.65 & 0.10 & 26.49 & 0.00 \\
FININ & 0.23 & 0.02 & 9.63 & 0.00 \\
\hline R-squared & 0.74 & Mean dependent var & 3.61 \\
Adjusted R-squared & 0.73 & S.D. dependent var & 0.08 \\
S.E. of regression & 0.04 & Akaike info criterion & -3.36 \\
Sum squared resid & 0.06 & Schwarz criterion & -3.27 \\
Log likelihood & 60.86 & Hannan-Quinn criter. & -3.33 \\
F-statistic & 92.81 & Durbin-Watson stat & 0.70 \\
Prob (F-statistic) & 0.00 & & \\
\hline
\end{tabular}

As per the regression results, financial inclusion explains only $74 \%$ of the income equality of the country while balance of $26.3 \%$ influenced by other variables which are exist outside from the study variables and the probability level (F-statistic 0.00) of the model is significant. The result of this model shows that financial inclusion (P-value 0.00) is significant at the $5 \%$ significant level. Constant value of the model is 2.65 . If there is no financial inclusion or zero financial inclusion, income equality of the country would be 2.65. Further coefficient for the financial inclusion is 0.23 . If financial inclusion increases by 1 unit, it leads to 3.17 increases in Gini coefficient. 
Durbin-Watson stat (0.699548) of the model is near to 0, since it implies the positive autocorrelation of the model. The hypothesis of $H 1 d$ can be accepted as per the statistical result of the model.

\section{Conclusion and Policy Implications}

There is a gap in the literature, especially in the local context, that must be bridged if efficient and effective strategies are to be developed for the inclusion of more people into the formal financial market, as a strategy for enhanced inclusive growth. Therefore, this study focused on identifying the significant impact of financial inclusion on inclusive growth in Sri Lanka. Therefore, the present study will provide insights into the body of knowledge on financial inclusion. According to the research findings, it was revealed that there is a significant positive influence made by the financial inclusion on inclusive growth in Sri Lanka. It indicated that for enchasing the degree of inclusive growth in the country, financial inclusion should be further improved. For this purpose, policy makers should be focused on to remove the barriers of financial inclusion. Further, findings explained that the most significant dimension of the inclusive growth was economic growth. Therefore, it was confirmed that financial inclusion is mostly influenced on economic growth among the other inclusive growth dimensions. When it comes to the least significant dimension of inclusive growth, which was influenced by the financial inclusion, is employment. Therefore, it is the important finding of the research as to which should be much improved for enchasing inclusive growth of the country.

\section{References}

Aduda, J. and Kalunda, E. (2012). Financial Inclusion and Financial Sector Stability with Reference To Kenya: A Review of Literature. Journal of Applied Finance \& Banking, 2(6), 95-120.

Agarwal, A. (2010). Financial Inclusion: Challenges \& Opportunities. 23rd Skoch Summit 2010.

Akudugu, M.A. (2013). The Determinants of Financial Inclusion in Western Africa: Insights from Ghana. Research Journal of Finance and Accounting, 4(8), 1 - 9.

Anand R., Mishra S. and Peiris J.S. (2013). Inclusive Growth - Measurement and Determinants, May, 2013, IMF Working Paper 13/135.

Anna Ellison, Claire Whyley and Rob Forster. (2010). Realizing banking inclusion: The achievements and challenges. Journal of Monetary Economics, 58(29), 66-89.

Arora, R.U. (2010). Measuring Financial Access. Discussion Paper Economics, 2010-7, Griffith University. ISSN1837-ISSN7750.

Beck, T., Demirguc - -Kunt, A. and Martinez-Peria, S. (2007). Reaching out: access to and use ofbanking services across countries. Journal of Financial Economics, 85(1), 234266.

Berger, A.N., and Udell, N.G. (2002). Small business credit availability and relationship lending: the importance of organizational structure. Economic Journal, 112, 32-53.

Bhanot, D., Bapat, V., and Bera, S. (2012). Studying financial inclusion in north east India. International Journal of Bank Marketing, 30(6), 465-484. 
Bill and Melinda Gates Foundation, (2015). Financial Services for the Poor. www.gatesfoundation.org.

Chakrabarty, K.C. (2010). Inclusive Growth Role of financial sector. Paper presented at the National Finance Conclave, Bhubaneswar- Orissa, India. 27th November.

Chakrabarty, D. and Chaudhuri, A. (2001). Formal and informal sector credit institutions and inter linkage. Journal of Economic Behavior \& Organization, 46(3), 313-325.

Devlin, J. F. (2009). An Analysis of Influences on Total Financial Exclusion. The Service Industries Journal, 29(8), 102-136.

Dixit, R. and Ghosh, M. (2013). Financial Inclusion for Inclusive Growth of India - a Study of Indian States. International Journal of Business Management \& Research (IJBMR), $3(1), 147-156$

Ellis, K. (2007). Is financial liberalization enough to promote financial inclusion? London: Overseas Development Institute.

Goacher, D.J. (1999). The Monetary and financial System, Published by Financial World Publishing.

Heenkenda, S. (2014). Inequalities in the Financial Inclusion in Sri Lanka: An Assessment of the Functional Financial Literacy, (Online) http://mpra.ub.unimuenchen.de/54419/MPRA Paper No. 54419, posted 16. March 2014 11:07 UTC. Hicks, J. (1969). A theory of economic history. Oxford: Clarendon Press.

Islam, M S. (2014). Microcredit, Financial Inclusion and Women Empowerment Nexus in Bangladesh. Journal of Asian Development Studies, 3(2), 7-15

Klasen, S. (2010). Measuring and Monitoring Inclusive Growth: Multiple Definitions, Open Questions, and Some Constructive Proposals, ADB Sustainable Development Working Paper Series, No. 12. Mandaluyong City, Philippines, Asian Development Bank.

Kumar, B. and Mohanty, B. (2011). Financial Inclusion and Inclusive Development in SAARC Countries with Special Reference to India. Vilakshan: The XIMB Journal of Management, 8(2), 13-22

Kumar, N. (2013). Financial inclusion and its determinants: evidence from India. Journal of Financial Economic policy, 5(1), 4-19.

Kumari, D.A.T. (2012). Financial intermediation development: A contributing factor to economic growth in Sri Lanka (With special reference to post liberalization of Financial sector in Sri Lanka, Wayamba Journal of Management, 3(1), 56 -74.

Kumari, D.A.T. (2016a). Financial Literacy as a Demand side Antecedent of Financial Inclusion: an Empirical Study among rural poor in Sri Lanka. Wayamba International Conference (WinC 2016).

Kumari, D.A.T. (2016b). Psychological barriers of under privilege rural customers in adapting to formal financial system: A study in a selected DS division of Kurunegala District. International Conference Faculty of Graduate Studies.

Levine, R. (1997). Financial Development and Economic Growth: Views and Agenda. Journal of Economic Literature, 35, 688-726. 
Magap, J.P., Okwanya, I. and Ojeka, G. (2015). Financial inclusion for inclusive growth: the nigerian perspective. International Journal of Information Technology and Business Management, 37(1), 1-8.

Onaolapo, A.A and Odetayo, T.A. (2012). Financial inclusion as tools for Survival in Globally competitive environment: Lessons for Nigerian microfinance banks. American journal of Business and management, 1(4), 241-247.

Park, D., Lee, S., and Lee, M. (2015). Inequality, Inclusive Growth, and Fiscal Policy in Asia. (C) Routledge. http://hdl.handle.net/11540/4341. License: CC BY-NC-ND 3.0 IGO.

Perera, R. (2015). Advancing Inclusive Financial System in the next decade, Shrestha, Min.B,The SEACEN Centre, 213-248.

Rauniyar, G. and Kanbur, R. (2010). Inclusive Development: Two Papers on Conceptualization, Application, and the ADB Perspective. Mandaluyong City, Philippines, Asian Development Bank.

Ramos, R.A., Ranieri, R. and Lammens, J.W. (2013). Mapping Inclusive Growth in Developing Countries, IPC-IG Working Paper, No. 105. Brasília, International Policy Centre for Inclusive Growth.

Robinson, J. (1952). "The Generalization of the General Theory; The rate of interest and other essays". London: Mackmillan.

Roy, S.K. (2012). Financial Inclusion in India: An Overview, Asian Journal of Multidimensional Research, 1(5), 136-138.

Serrao, M., Sequeira, A.H. and Hans, B.V. (2013). Designing a Methodology to Investigate Accessibility and Impact of Financial Inclusion (March 18, 2012). http://ssrn.com/abstract=2025521 or http://dx.doi.org/10.2139/ssrn.2025521

Schumpeter, J. (1911). The Theory of Economic Development: An Inquiry into Profits, Capital, Credit, Interest and the Business Cycle. Cambridge: Harvard University Press.

Shankar, S. (2011). An Analysis of the role of microfinance programs in promoting financial inclusion in India. $\mathrm{PhD}$ Thesis, National University of Singapore.

Thorat, A. (2006). Rural Poor: Who Are They and Why? A Case Study of Madhya Pradesh, Journal of Social and Economic Development, Institute for Social and Economic Change, Bangalore, 8(1), 41-67.

Verma, S. and Aggarwal, K. (2014). Financial inclusion through Micro Finance Institutions in India. International Journal of innovative research and development, 3(2), 178183.

Vellala, P.S., Madala, M.K. and Chhattopadhyay, U. (2014). A Theoretical Model for Inclusive Economic Growth in Indian Context. International Journal of Humanities and Social Science, 4(13), 229-235.

Yunus, M (2011). Vision 2050: A Poverty-Free World Social Business - A Step Toward Creating A New Global Economic Order. The Journal of Social Business, Social Business and New Economics Paradigm, 1(1), 7-23.

Zuleika Arashiro, (2010). Financial inclusion in Australia Towards transformative policy. Social Policy Working Paper No.13, Melbourne. 